\title{
'The MUlTIPle READINGS OF 'METAPHOR' IN THE ClASSROOM: CO-CONSTRUCTION OF INFERENTIAL CHAINS
}

\author{
(As múltiplas leituras da 'metáfora' em sala de aula: \\ co-construção de cadeias inferenciais)
}

\author{
Mara Sophia ZanotTo \\ (Pontifícia Universidade Católica de São Paulo - BRASIL)
}

\begin{abstract}
This paper is part of a research project whose central aim is to empirically investigate the multiple readings of 'metaphors' in literary texts. The methodology employed is interpretive and the main research technique is the 'Group-Think Aloud'. In this paper, the data discussed were generated by a group of readers engaged in the reading of 'The Pulverized Mountain', a poem by Drummond de Andrade. The analysis focuses on the interpretations of the final verses that, due to incongruities presented, constitute enigmas for the reader to decipher. Analysis has shown that the apparent data chaos and complexity has, in fact, an organization in inferential chains co-constructed by metonymic and metaphoric processes.

Key-words: metaphor; metonymy; interpretive methodology; inferential chain.
\end{abstract}

Resumo: Este trabalho faz parte do projeto de pesquisa que tem como objetivo central investigar empiricamente as múltiplas leituras de metáforas em textos literários. A metodologia é a interpretativista e a técnica principal de pesquisa éo 'Pensar Alto em Grupo'. Neste trabalho são discutidos os dados de um grupo de leitores lendo o poema 'A Montanha Pulverizada', de Drummond de Andrade. O foco da análise são as interpretações dos versos finais, que, devido às incongruências que apresentam, constituem enigmas para o leitor decifrar. A análise mostrou que o aparente caos e complexidade dos dados têm, de fato, uma organização em cadeias inferenciais co-construídas por processos metonímicos e metafóricos. Palavras-chave: metáfora; metonímia; metodologia interpretativista; cadeia inferencial. 


\section{INTRODUÇÃO}

The research reported here is part of a research project ${ }^{1}$ whose central aim is to empirically investigate the multiple readings of 'metaphors' ${ }^{2}$ in literary texts. After presenting the assumptions of this project - developed within the qualitative research paradigm - I will explain how the idea of coconstruction of inferential chains by metonymic and metaphoric processes became a matter for investigation in data analysis, since the data were not generated with that objective in mind; rather it occurred as a force that made its way to the centre of analytical process

This project is developed within the Applied Linguistic area because, based on Rojo (2006) and Moita Lopes (2006), I consider that the aims of investigation in Applied Linguistics are: a) "the solution of contextualized problems, that are socially relevant and connected to language use and discourse;" (Rojo 2006: 258), and b) the construction of relevant results and useful knowledge for participants of the investigated social practice, taking into account their interests and perspectives (Moita Lopes 2006).

Taking this concept of Applied Linguistics into account, the relevant social problem on which the research focuses is the teaching-learning of reading, which has been regarded, in recent evaluations such as ENEM, $\mathrm{SAEB}^{3}$, as one of the greatest educational problems in Brazil - since the results achieved in these assessments have shown students' low level of performance in secondary schools when it comes to reading and writing.

Although some new projects for the teaching of reading have been proposed by the Educational Department of the State of São Paulo, the teachers do not feel prepared to implement them in the classroom. For this reason, the Educational Department of Sao Paulo has created a scholarship system by which public school teachers can attend Master and Doctorate

1. The project entitled "The Multiple Readings of 'Metaphor' in the Classroom: Theoretical and Pedagogical Complexities" is being developed with the support of CNPq (National Council for Scientific and Technological Development - Brazil).

2. I will refer to 'metaphor' in between inverted commas because the nature of the investigated phenomenon will - throughout this paper - be object of discussion.

3. ENEM and SAEB are exams carried out by the Anísio Teixeira National Institute for Educational Studies and Research (INEP - Instituto Nacional de Estudos e Pesquisas Educacionais). SAEB is the Assessment System for Basic Education; ENEM is the National Exam for Secondary School Teaching. 
Programs. With the creation of this scholarship, the Postgraduate Program in Applied Linguistics of PUC-SP (Pontifical Catholic University of São Paulo) is one of the programs that has been receiving public school teachers for the Master and Doctorate courses. Therefore, the research that I present here has 4 public school teachers and 2 teachers from the private sector as participants.

One of the problems that these teachers face daily is how to prepare their students for the ENEM assessment - an exam that allows students who achieve the required score to have access to university by receiving a governmental scholarship called PROUNI, whose idea is to promote inclusion. For this reason, I decided to choose, for this investigation, a poem written by Drummond de Andrade that was used in ENEM exam of 2006.

When reading a poem like this, what generally causes problem is the figurative language due to the incongruities that it creates and to the multiple readings that appear when the reader tries to solve these very incongruities. This is what the data generated by the participants of the social reading event will show in the Data Analysis Section.

Before presenting the methodology, data analysis and final reflections, I will discuss some assumptions of post-modern Applied Linguistics and their implications for the teaching-learning of reading that are the basis of the practice of thinking aloud in group, or Group Think-Aloud (Zanotto 1995, 1998; Zanotto \& Palma 2008) considered, in this research, as a pedagogical experience and a research technique. I will also present a discussion on the issue of the multiple readings of figurative language and on interaction between metaphor and metonymy in the co-construction of inferential chains.

\section{Reading as a social practice in post-modern Applied LiNGUISTICS}

The traditional teaching of reading, that is based on the assumption of a single reading, has been supported by the view of communication as a telemental process, accepted by modernist Applied Linguistics (AL), according to Pennycook $(1998,2001)$ - and also accepted by common 
sense, as Reddy (1979/1993) has demonstrated with the conduit metaphor. The traditional practice of reading results from this view, working with the assumption that meaning is in the text regardless of the reader's subjectivity and his/her context - in this view, there's no need to leave room for the reader's voice and subjectivity, since the reader's job is only to 'get the meaning that is already there'.

Based on postmodern assumptions, critical applied linguistics deconstructs the dogmas of modernist AL (Moita Lopes 2006) and rethinks the means by which we see language, meaning, communication and reality. Postmodern Applied Linguistics proposes the understanding of language as an ideologically committed social practice. In this view, it is impossible to understand language autonomously, regardless of the socio-cultural-historical context in which it occurs, free of an ideological commitment. Meaning is then seen as multiple and indeterminate. From these assumptions, research methodology is changed, especially as a consequence of the epistemological assumption that subjectivity is a part of knowledge construction. Thus, Moita Lopes' assertion (2006: 31) that “it is inadequate to construct theories without considering the voices of those that live the social practices that we seek to study", therefore adopting a contrary position to positivism that has silenced many voices (Denzin \& Lincoln 1998).

If, on one hand, from the methodological perspective, postmodern $\mathrm{AL}$ is opposed to the silencing of the subject, proposing methodologies such as the interpretive, whose essential concern is to listen to the voices of those who live the investigated social practices; on the other hand, from the perspective of the teaching of reading, I would say that the situation is still that of the telemental concept of communication. Thus, although there is theoretical recognition that meaning is not determined, nor independent from the reader's subjectivity, research on reading has not dedicated enough attention to the question of providing space to the voice of the reader and, consequently, to the construction of multiple readings, with few exceptions, like Mandel (1987) and Kempe (2001).

Therefore, the postmodern paradigm still has a lot to develop in the area of the teaching of reading (and also in metaphor and literacy studies), in the sense of not only considering in theory, but also in practice the question of indeterminate meaning. This shows that this paradigm has still not been made concrete in all its essential points. 
Since I have been working for several years with multiple readings of metaphor, I have been, from the beginning, concerned with giving voice to students, during reading events, so that they could establish an uncommitted dialogue with the text, and then different readings could be constructed spontaneously. For this to happen, I have been using the research technique of Group Think-Aloud (Zanotto 1995, 1998; Zanotto \& Palma 2008), which has revealed a great pedagogical potential. The greatest gain of this pedagogical experience is the fact that students can become aware of their 'own ontological power' (Mandel 1987) ${ }^{4}$ of constructing senses for themselves, which makes them more self-confident, reflective and critical.

As I have mentioned, the participants of this research are teachers/ students, who have experienced the reading practice of thinking aloud in group about the text written by the Brazilian poet Drummond de Andrade: A Montanha Pulverizada (The Pulverized Mountain). The aim was to have them experiencing this practice so as to be able to apply it in their classrooms, later, as researchers of their own actions, thus reflecting about their own roles in this social reading event - a role that includes giving students voice, hearing, validating and orchestrating (O'Connor \& Michaels 1996) their voices, besides mediating the reading constructions. As this Group Think-Aloud is a democratic literacy event in which all participants have the right to express their ideas, it requires the teacher to meaningfully review his/her roles, considering that besides giving voice to the student, he must also be able to silence and listen, respecting "the multiple means of conceiving, understanding and analyzing reality" (Kleiman 2006: 88). For this reason, the practice of Group Think-Aloud, defined as per the assumptions of the post-modern paradigm, constitutes a pedagogical complexity that deserves to be investigated in depth so that a larger number of teachers can use it as researchers of their own practices.

However, in order to make the implementation of a postmoderncoherent reading practice become a reality, it is essential to explain the multiple readings constructed by the participants. For this reason, this research project aims at both contributing to the construction of a reading

4. Mandel (1987) presents an interesting discussion about the teaching of literature, whose strongest argument is that in literature classes, students, in general, "have little or no idea of their ontological power of making sense for themselves" (1987: 107). And, in order to solve this problem he works with 'ego responses', i.e., he gives space to students' subjectivities in the reading of literary texts. 
practice for the classroom setting, and shedding light on the issue of multiple readings.

\section{Multiple Readings of figurative language}

While carrying out an empirical research as the one here described, in which one investigates how real human beings understand the highly undetermined phenomenon that is metaphor, the complexity of the data leads us to confront some of the challenges that have been presented to metaphor researchers by Gibbs (2006): 1) What does 'metaphor' actually mean? 2) How can one count or individuate the readings of 'a metaphor'? Or the following questions related with relevance of the readings: Could relevance (Sperber \& Wilson 1986) help to select a more relevant reading? Or do all readings present the same degree of relevance?

In order to answer these questions, it is necessary to theoretically explain the nature of readings, establish their relation with the text, or the factors that were taken into account in the construction of such readings, so as to analyze which readings can be accepted as valid from the relevance perspective. To the present moment, this issue has been treated intuitively by readers, i.e., we reflect about the readings constructed by participants by taking into account the relationship with the text and the knowledge we have about the author.

In the case study reported by Zanotto \& Palma (2008), for example, when working with the readings of what we initially thought to be a metaphor vehicle, we were confronted with the product complexity of several readings constructed in inferential chains by means of metonymic and metaphoric processes (Moura \& Zanotto 2009). These data lead us to question the very nature of what we were investigating: how could we continue to call 'metaphor' something that was constructed by metonymic and metaphoric processing? (Zanotto \& Palma 2008:37). In other words, that which theoretically seems to be a clear and determined phenomenon, in language-in-use reveals itself to be a network of meanings and processes that challenge theories to explain its nature.

This case study, and the data discussed in this paper, showed us the importance of carrying out more empirical qualitative researches that 
investigate in depth the interaction between metaphor and metonymy so as to clarify the nature of what I have termed 'the metaphor' for the time being; i.e., the question remains as to what this new phenomenon that is arising from the interpretation by actual readers of 'metaphor'-in-use will be called. Would Goossens $(1990,2002)$ be correct to call it 'metaphtonymy' as in his seminal paper? I consider this question still to be answered by metaphor and metonymy scholars. What I mean is that I think that it is still necessary to carry out further empirical research of this nature, i.e., case studies with several groups of readers freely constructing readings, without any previous commitment.

If it is so complex to theoretically explain the product of readings, one can conclude that for the teacher, in the classroom, multiple readings constitute an even greater level of complexity. For this reason, the multiple readings constitute, first of all, a theoretical problem, and then, a pedagogical problem. This order does not mean that the pedagogic component is less important; it means that it is necessary to theoretically explain the nature of readings, the relation that they have with the text, or the factors that took part in their construction so as to analyze which readings can be accepted as relevant, and which cannot.

As I have said initially, the focus on interaction between metaphor and metonymy in the co-construction (Jacoby \& Ochs 1995) of inferential chains emerged in the process of data analysis. Data were not collected with the purpose of focusing on this matter, but to explain the process of co-construction of multiple readings, as well as discussing its product. Nonetheless, in order to accomplish such objectives, it was necessary to discuss the metaphor-metonymy interaction and the inferential chains. For this reason, before going to the methodology and data analysis sections, it is necessary to briefly present some studies carried out about the metaphormetonymy interaction, since they have proved to be relevant for the data analysis in the case of this paper.

\section{INTERACTION BETWEEN METAPHOR AND METONYMY IN THE CONSTRUCTION OF INFERENTIAL CHAINS}

In the study reported by Zanotto \& Palma (2008), the analyzed data revealed a complex interaction between metaphor and metonymy in the 
construction of different readings. One way of explaining this interaction was carrying out the analysis of inferential chains (Moura \& Zanotto 2009) - which resulted in the perception that the chains were constructed by metonymic processes, and, in general, it was metonymy that functioned as the basis (or the mediation) for the construction of metaphorical readings, thus confirming the hypothesis of Barcelona (2000) that metaphor is, in general, motivated by conceptual metonymy.

This finding led us to examine studies related to the interaction between metaphor and metonymy, beginning with Goossens (1990, 2002), whose work on English expressions of action demonstrated several types of interactions which he called "metaphtonymies", and which are divided into two basic types: a) integrated metaphtonymy and b) cumulative metaphtonymy. Integrated metaphtonymy is "the type in which in one and the same expression a metonymy and a metaphor are combined" (Goossens 2002: 369). This type of metaphtonymy is further divided into two sub-types: metonymy within metaphor, or, less commonly, metaphor within metonymy. The second type, the cumulative metaphtonymy, "implies that a metaphor is derived from a metonymy or vice versa". In this case a metaphor from metonymy can occur, or, less commonly, a metonymy from metaphor.

In more recent studies, the role of metonymy has been investigated in the inferential construction of meanings which, according to Barcelona (2007:54), "had already been studied by a number of cognitive linguists, though much more still has to be done". Some studies have also pointed to the fact that inferences constitute inferential chains of metonymic processes, or chained metonymies (Barcelona 2000, 2002, 2007; Hilpert 2007). These chains have mostly been studied as phenomena that occur in lexicalization and grammaticalization (See Hilpert 2007) and, less frequently, in the construction of meanings in the interpretation of texts (Barcelona 2007).

In this paper, data revealed inferential chains by metonymic and metaphoric processes constructed by different participants in the group interaction. Due to space limitation it will not be possible to deepen the different roles of metonymic inferences in the construction of meanings, a matter for future discussion. 


\section{Methodology}

The qualitative methodology has proven adequate for the investigation of multiple readings, especially that of the interpretive frame (Denzin \& Lincoln 1998), whose essential concern is to listen to the voices of those who experience the social practices that are investigated (Moita Lopes 2006). The main research technique is that of Group Think-Aloud, which, in the view of Zanotto \& Palma (2008:16), is "a socio-cognitive re-interpretation of traditional Think-Aloud procedure (Ericsson \& Simon 1984), based on meta-research on this technique carried out by Cavalcanti \& Zanotto (1994)." This technique is perfectly attuned with the main assumption of interpretive methodology: to listen to the voices of students/readers, since it is a literacy event (Street 1984; 1993) of democratic nature, whose main objective is to give voice to the readers and, above all, listen and validate their voices.

The Group Think-Aloud technique data were triangulated with data from retrospective interviews and from subjects' diaries of reading so as to allow for a greater proximity to the studied phenomenon (Zanotto \& Palma 2008). However, in this paper, the data analyzed are all from one single Group Think-Aloud event.

Considering that this is an investigation about multiple metaphor readings, it is essential that the data be generated with several groups, so as to allow for verifying stability or variation of readings, coherent with a view of metaphor in use as dynamic, rather than static (Cameron 2008; Zanotto, Cameron \& Cavalcanti 2008). Therefore, the instrumental collective case study design (Stake 1998), by following interpretive methodology, has proven to be the most adequate design for the objectives of the research. The reason for a case study to be considered instrumental is that it is "a particular case which is examined to provide insight on an issue or to refine a theoretical frame" (Stake 1998:88). In this research, the case will be examined in depth to shed light on the question of the multiple readings of metaphor. Due to the fact that the research is carried out with several groups (cases), the research is a collective case study, i.e., "an instrumental study extended to several cases" (Stake 1998:89).

The first case study concluded was reported in Zanotto \& Palma 2008. The case reported here is the second case in construction. Until the present 
moment, three groups have experienced the Group Think Aloud, with the same poem and the objective is to have six groups experiencing the task. In this paper, the analysis will focus more closely on the data from one group that will be complemented with data from the other two groups.

The participants of the social reading event, whose voices are analyzed in this paper, were students from the course on Literacy and Reading that I taught at the Postgraduate Program on Applied Linguistics and Language Studies, during the first term of 2008. The teachers / students chose their own fictional names: Fernanda, Sosô, Sócrates, Asdrúbal, Eulália, Juliana and Nete. Except for Fernanda - who is a speech therapist - they were teachers -4 of them in the public sector (at primary and secondary schools) and 2 of them in the private sector (at universities).

In the last class of the first term, we met in order to experience thinking aloud in group on a text written by Drummond de Andrade - A Montanha Pulverizada [The pulverized mountain] - which had been used in the National Exam for Secondary Schools (ENEM) in 2006. The proposal was that we would, first of all, read the text and collaboratively think aloud having no commitment with the mentioned exam or with any other school task. We aimed at verifying what readings would be constructed so as to later confront them with the questions found in the exam.

\section{The text}

The test used only the last stanza of the original poem. First of all, I will present the poem as it was seen in the test. In the end of the data analysis section, I will show the full poem, though the questions asked and the discussion about them will not be included in this paper due to space limitation. 


\begin{tabular}{|l|l|}
\hline A Montanha Pulverizada & The Pulverized Mountain \\
Esta manhã acordo e & It's morning, I wake up and \\
Não a encontro. & Can't find it \\
Britada em milhões de lascas & Drilled into millions of fragments \\
Deslizando em correia transportadora & Sliding down the transportation belt \\
Entupindo 150 vagões & Filling up 150 railway carriages \\
No trem-monstro de 5 locomotivas & In the 5 engine monster-train \\
- trem maior do mundo, tomem nota - & The biggest train in the world, do write it down \\
foge minha serra, vai & My mountain runs away \\
deixando no meu corpo a paisagem & Leaving behind in my body its landscape \\
mísero pó de ferro, e este não passa. & Vile iron dust, and this does not go away. \\
& \\
Carlos Drummond de Andrade. Antologia & Translation by Sandra Madureira \\
Poética. Rio de Janeiro: Record, 2000. & \\
\hline
\end{tabular}

\section{DATA ANALYSIS}

When I suggested that we read this text, Asdrúbal reacted as if to show boredom, because he had already taken part in another experience with the same text in another course ${ }^{5}$. Juliana had not read the text yet, but following a quick look through, she reacted by saying:

\section{Extract 1}

1 Juliana I don't know... I think that my "metaphormeter" is turned off... to me... for me this is all so "plain"!

Teacher I see, I see.

Juliana It is a situation that is there; he is describing it... I'm telling you people 5 ... I don't see any metaphor...

Teacher No, but you don't need to worry with metaphor...

Juliana Someone's taken it... A lot of trucks came and took it away in the train... The last part is a bit confusing, isn't it?

I call the attention to this initial reaction from Juliana and Asdrúbal because they are the ones who will actually co-construct interesting readings. On lines 1 and 2, Juliana says that she cannot see any metaphor because her 'metaphormeter' is turned off, and to her the text is "so plain"! On lines 7 and 8 she says that a number of 'trucks came and took it (the pulverized mountain) away in the train', meaning to say that this was the

5. Three of the seven participants had already taken part in another experience with the same text in another course. These were: Eulália, Asdrúbal and Nete. 
only thing that happened. However, she makes a short pause and finishes by recognizing that the 'the last part is a bit confusing, isn't it?' This last part is precisely what will allow for more discussion in this group, as we will see later. In fact the final verses present a lot of incongruities ${ }^{6}$ (Cameron 2003; Moura \& Zanotto in press) that constitute riddles for the reader to solve:

Foge / minha serra, / vai deixando no meu corpo / a paisagem/ mísero/ pó de ferro, e estel não passa
My mountain / runs away

/ Leaving bebind in my body / its landscapel

Vile/ iron dust, and this / does not go away

Before discussing this final part, however, the group talks about the text, contextualizing the poem, and conclude that Drummond refers to the mountains of the Brazilian State of Minas Gerais (General Mines), where there is great exploitation of minerals. And they raise the possibility that the poet may be speaking of the city in which he was born and where he was raised: Itabira ${ }^{7}$. The poem also leads them to discussing environmental issues and the ontological metaphor of the mountain as a person, in my mountain runs away. Asdrúbal remembers that during the other experience

6. In literature about metaphor, the syntactic-semantic or pragmatic rupture that constitutes the essential condition for linguistic metaphor (Cameron 2003), has received several different names: deviance, anomaly, incongruity, incompatibility. In pragmatics, Searle (1979) and Grice (1975) considered anomaly a 'defective' literal that would be necessary for the search for a non-literal meaning (implicatures, metaphor, irony, etc.). This led to the stage model of metaphor comprehension which basically consists of perceiving the incongruity (first stage) and trying to solve the incongruity (second stage). This model frequently occurs in metaphor comprehension data from literary texts, as will be seen in the data here analyzed. (For further discussion see Moura \& Zanotto (2009))

7. Itabira is a city in the State of Minas Gerais, state that received this name due to the number of mineral beds that it has. Itabira is especially very rich in iron ore, so much that Drummond shows, in his poem:

Confidência do Itabirano (Confidence of an Itabiriant the importance of the presence of iron ore for the people who live in this city:

"Alguns anos vivi em Itabira. [Some years did I live in Itabira]

Principalmente nasci em Itabira. [And mainly, I was born in Itabira]

Por isso sou triste, orgulhoso: de ferro. [For this reason, I am sad, proud: iron like]

Noventa por cento de ferro nas calçadas. [Ninety per cent iron on the footpaths]

Oitenta por cento de ferro nas almas. [Eighty per cent iron in the souls]

E esse alheamento do que na vida é porosidade e comunicação" [And this strangeness of what is porosity and communication in life]

Itabira is an Indigenous name., that means raised (or pointy) rock (as is the case of Pico do Cauê, which was the inspiration for the Pulverized Mountain), that was 5 kilometers from Fazenda do Pontal, the farm that belonged to the poet's family until 1954). 
he had in reading the same poem, the teacher had read this metaphor as an expression of an intimate relationship that Drummond had had with the mountain. After this, Asdrubal leads the discussion to the final verses, as can be seen at the beginning of extract 2 :

\section{Extract $2^{8}$}

1 Asdrubal Now this part of vile iron dust, and this does not go away ... wouldn't it be about... the harm that it causes?

Juliana uh, true...

Asdrubal Isn't it, of the harm that the extraction causes to people... this... the result of all this ....

Eulália This vile iron dust is criticism ...

Asdrubal Of how harmful it is for people... people end up inhaling this dust, don't they? Teacher So are you thinking of the actual inhaling?

Asdrubal Yes, because he says, look...my mountain runs away, leaving behind in my body its landscape ...look... I'm reading this landscape as if it were the vile iron dust ...so it is leaving behind in my body the vile iron dust and it doesn't go

away...

You mean like these intoxications?

Asdrubal Yes!

15 Teacher You know... I hadn't thought of that... I think this reading is really quite possible...

Juliana Well then it would be quite ... criticism... it would be criticism ...

Asdrubal It doesn't only get the affective aspect with the mountain.

Teacher It is a kind of criticism... it is funny, Asdrúbal, that when I read... I thought of vile iron dust that does not go away... I thought on the pain of seeing the mountain be destroyed and this pain wouldn't go away... because you speak of a pain that does not go away, but not of iron dust that does not go away... you know what I mean... but I think your reading is quite possible... because ... but I think it does not go away ... I mean... he... you inhale it... and the consequences are in your body.... I don't know what kind of consequences one can have from iron inhaling... it would be something to /

Fernanda But it is the disease that does not go away, does not leave...

Teacher The disease that does not go away, yes it could be...

Sócrates The iron dust... the landscape that he keeps that it is only this iron dust /

30 Asdrubal That is in his body...

Teacher But look, the last time you didn't make this reading... do you see? ... and now, you did... how interesting.. and I think that it makes a lot of sense, doesn't it?... because really, he inhales the dust and then the landscape is in his body due to the inhaled dust.

8. In the extracts of the social reading event, the words of the poem that are mentioned by the students in the process of interpretation are signaled in italics, and the key words that are important for the interpretations are underlined. 
Asdrúbal (lines 1-2) goes back to the final verse of the poem: vile iron dust, and this does not go away - and interprets it as being the harm that it causes people, thus constructing an inferential reading, guided by a CAUSE FOR EFFECT metonymy, whereby the CAUSE - vile iron dust that does not go away - leads to the EFFECT - the harm. This metonymy is made explicit by Asdrúbal when he says: the harm it causes.

Juliana agrees, and Asdrúbal goes on to explain that he was thinking about "the harm that the extraction causes to people" - or "the result of all this" (lines 4 and 5). This speech shows another metonymic inference, since he does not mention the vile iron dust; rather it shows a cause: iron ore extraction, i.e., he is constructing another inference guided by a CAUSE FOR EFFECT metonymy. In his reasoning, we can see the construction of a metonymic chain, since extraction is the cause of iron dust, that, in turn, is the CAUSE of harm (EFFECT). We can also see that he is restating the initial interpretation of the effect caused by iron dust, but by using indeterminate terms such as harm and result. These are generic terms that may be specified, because we can ask what type of harm or result. And we will see that the harm will be specified by the readers in two paths: physical effects and emotional effects.

On line 6, Eulália constructs a pragmatic inference mediated by Asdrúbal's thought, saying that "this vile iron dust is criticism". This inference of the illocutionary force of the poem is also guided by a CAUSE FOR EFFECT metonymy.

Therefore, on lines 1-6, Asdrúbal and Eulália co-constructed the following inferential chain:

Vile iron dust and this does not go away $\rightarrow$ CAUSE FOR EFFECT metonymy $\rightarrow$ harm or $\underline{\text { result }} \rightarrow$ CAUSE FOR EFFECT metonymy $\rightarrow$ criticism.

Asdrúbal does not show any sign of hearing Eulália's reading as criticism, because he seems to be concentrated on his own reasoning, and, on line 7, he carries on with his analysis, seeking to make the harm more specific, by saying that it is caused by inbaling iron dust, i.e., the indeterminate idea of harm will now follow a path of specification or precisification's in the

9. Pinkal (1995) and Poesio (1995) proposed the Precisification Principle, according to which "lexical meaning is intrinsically undetermined and can be precisified in many ways, according to the context." (Zanotto \& Moura 2002:4) 
discussion. The teacher revoices (O’Connor \& Michaels 1996) Asdrúbal by saying: So are you thinking of the actual inbaling?

Asdrúbal confirms that it is indeed the inbaling of the iron dust (line 9) and continues his reasoning, saying that, in his reading of the two previous verses (my mountain runs away, leaving behind in my body its landscape), he understands 'this landscape as if it were the vile iron dust' (lines 9-11). When he says as if it were, he is showing metaphoric reading, though he does not explicitly show any metaphoric mapping. However, on the basis of my own reading, it seemed as if there were an implicit metonymic relation, WHOLE FOR PART, in other words, what is inhaled - the iron dust - is part of the landscape, that is the whole. He finishes his reasoning by constructing a paraphrase in which he replaces landscape by vile iron dust: 'so it is leaving behind in my body the vile iron dust and it doesn't go away'. This paraphrase demonstrates that the substitution is an important strategy to monitor the understanding process (Zanotto \& Palma 2008), since the reader uses substitution to check if the incongruence was solved.

Juliana (line 13), in turn, shows that she is following Asdrubal's reasoning, and contributes to specifying the generic term harm, by asking if Asdrúbal is thinking of the intoxications. Asdrúbal (line 14) confirms Juliana's idea, and the teacher (line 15) says that she had not thought of this reading before. Juliana then concludes that these verses have the illocutionary force of criticism, the same pragmatic inference constructed by Eulália guided by a CAUSE FOR EFFECT metonymy (line 6).

Asdrúbal (line 18), then, agrees with Juliana saying that there is not just the affective side in relation to the mountain (as the group had previously discussed), but that of criticism as well.

Trying to summarize the readings constructed in lines 7 to 19 , it is possible to say that they form the following inferential metonymic chain, beginning with Asdrúbal retrieving his analysis (that had been interrupted by Eulália when interpreting the illocutionary force of these verses as criticism) - and continuing from where he had stopped: harm:

$\underline{\text { Harm }} \rightarrow$ EFFECT FOR CAUSE metonymy $\rightarrow$ inhaling iron dust $\rightarrow$ PART FOR WHOLE metonymy and clues of metaphorical reasoning: as if it were $\rightarrow$ landscape // inhaling iron dust + leaving bebind in my body the vile iron dust (as if it were landscape) $\rightarrow$ CAUSE FOR EFFECT metonymy $\rightarrow$ intoxications $\rightarrow$ CAUSE FOR EFFECT metonymy $\rightarrow$ criticism 
The construction of this inferential chain is guided by several types of metonymy: EFFECT FOR CAUSE, PART FOR WHOLE and CAUSE FOR EFFECT (two incidences) and metaphorical reasoning.

The teacher then says that when she read the poem, she thought of the pain (lines 19-21) of seeing the mountain destroyed (reduced to dust), a pain that would not go away. In order to justify the reading of pain, which is also activated by a CAUSE FOR EFFECT metonymy, she reminds them of the language use (lines 20-23), in which we can say in Portuguese: a dor não passa (the pain does not go away) ${ }^{10}$, but that we cannot say o pó de ferro não passa (the iron dust does not go away). She is using the strategy of substitution to check if the metonymic inference has solved the incongruity, replacing 'vile iron dust' for 'pain' ${ }^{11}$.

Fernanda, then, replies (line 27) that one can also speak of a doença não passa_(disease that does not go away), another common collocation in Portuguese. They are trying to solve the incongruity in this iron dust doesn't go away, but, in fact, are constructing other incongruities, like a doença não passa (the disease doesn't go away) or a dor não passa (the pain doesn't go away), that are not felt, however, as incongruities since they are common collocations in Portuguese. The phenomenon by which the regular reader constructs incongruent, though, conventional paraphrases throughout the process of metaphor or metonymy interpretations shows a need to rethink the idea that "incompatibility requires the interlocutors to construct meanings in order to reconcile the conflict between expressions." (Radden et al 2007:7)

On lines 29 and 30, Sócrates and Asdrúbal co-construct a poetic synthesis of the interpretation when Sócrates says that 'The iron dust... the landscape that he keeps that it is only this iron dust, and Asdrúbal promptly completes: 'that is in his body'. Therefore Asdrúbal is paying a lot of attention to the incongruity in the excerpt 'leaving behind in my body the landscape', which his reading seems to solve.

Summarizing the readings constructed on lines 19 to 30, we have the following chain:

10. This is a common collocation in Portuguese, but also incongruent.

11. The teacher's reading here will be justified in another excerpt. 
Vile iron dust that does not go away $\rightarrow$ CAUSE FOR EFFECT metonymy $\rightarrow$ pain $\uparrow^{12}$

Vile iron dust that does not go away $\rightarrow$ CAUSE FOR EFFECT metonymy $\rightarrow$ disease

The previous Asdrúbal's metonymic reading will function as a mediator for Juliana to construct an interesting metaphorical reading on extract 3:

\section{Extract 3}

1 Teacher (to Asdrúbal) Did you see? We need two experiences to be able to complete this reading...

??? the poor ENEM candidates had 15 minutes with who knows how many thousands of other questions to solve...

5 Asdrubal I'll keep quiet (?) my colleagues. But there is something that... that was bothering me the last time, but I couldn't... do you know when something is in your head, but you just can't decipher the reading?

Teacher What you read makes a lot of sense because leaves in my body the landscape, means... of course, $\underline{I}$ am inhaling the landscape.

10 Juliana You know, I'm thinking that besides this, besides inhaling the landscape... I cannot not be my past, right?... I think ... I'm not even sure... but I'll analyze it from what I remember... but I think ... that when you make an X-ray of a person, you have the lungs' tree, full of iron, forming an image of a tree, as if it were a landscape...

In this extract, in lines 1-2, the teacher speaks to Asdrúbal, saying that although he did not seem very interested at the beginning of the experience, in the end, he constructed a reading that could solve the incongruities in the final verses. Someone that could not be identified in the recording makes a comment about the situation of ENEM examinees who have little time to solve the questions (lines 3-4).

On lines 5-7, Asdrúbal says that he thought that he had intended to keep quiet so as not to prevent his colleagues from constructing meaning. However, he says that something had been bothering him (since the

12. I am using the symbol $₫$ to indicate a relationship of opposition between the two readings, since one refers to an emotional effect (pain), while the other refers to a physical effect (disease). I understand that there is a certain opposition, though I am not thinking of an objectivist reading, i.e., that a reading could exclude the other. On the contrary, they can be complementary. I also consider the opposition as a means of constructing an inferential network. 
previous experience with the same text), and had been in his mind, but he had been unable to decipher this 'thing'. Therefore, we can see that incongruities constitute enigmas that must be solved by the reader, and that do not allow for easy solutions. This group experience stimulates and supports the student to solve these enigmas.

On lines 8 and 9 the teacher says that Asdrúbal's reading had made a lot of sense because leaving behind in my body the landscape means that I'm inhaling the landscape. Thus, the teacher, summarizing Asdrúbal's interpretation, constructs a paraphrase that is as incongruent as that of the poem's, which indicates the reader's tendency to continue to think metonymically and/ or metaphorically when constructing the interpretations. Then, Juliana, revoicing the teacher, says that, besides inhaling the landscape, there was something more. However, before saying what it was, she says that she cannot leave her past behind. ${ }^{13}$ " This knowledge will help her to say what this 'something more' was all about when she constructed a metonymic inference of the CAUSE FOR EFFECT type, thinking of the effect of the disease in the lungs (Asdrúbal's reading), which becomes evident on an $\mathrm{X}$-ray. This metonymic inference constitutes a mediator for a metaphorical reading (although she claims to be unsure of what she is saying): but I think ... that when you make an X-ray of a person, you have the lungs' tree, full of iron, forming an image of a tree, as if it were a landscape... She therefore constructs a metaphor from a metonymy, as Goossens (2002) would say, by using Asdrúbal's reading to mediate her metonymic and metaphoric inferences. In other words, she is building a metaphorical reading, by mapping the image of lung tree that is seen in the X-ray onto the image of the landscape, i.e., an image metaphor (Lakoff 1993) from a metonymy.

Due to Juliana's doubt about her reading (as well as the group's), I investigated with doctors (pneumologists) if this was a reasonable reading. The information I obtained was that, when inhaled, the iron ore dust causes a serious disease in the lungs: pneumoconiosis by intoxication. This disease provokes fibrosis in the bronchi, which become rigid, therefore becoming more visible on radiographic films, in which they form a tree image. We, therefore, saw that these metonymic and metaphoric inferences require very specific knowledge.

13. She was referring to an experience she had had with an uncle who worked in and lived close to a steel company. The group knew this information because she talked about it in another moment of the reading event. 
Consequently, Juliana's reading formed an inferential chain that started off with Asdrúbal's reading that the landscape, when reduced to dust, was in fact in the poet's body (that may be speaking as a miner that has the disease), causing the disease, an intoxication. The effect of this disease would be the rigidity of the bronchi, that would alter the radiological image of the lungs, showing the effect of a tree image. In the extract 3, the following inferential chain was therefore constructed, starting with Asdrúbal's reading:

Inhaling the landscape (iron dust) $\rightarrow$ disease (CAUSE FOR EFFECT metonymy) $\rightarrow$ lungs' tree full of iron (CAUSE FOR EFFECT metonymy) $\rightarrow$ X-ray: image of a tree $\rightarrow$ metaphorical mapping $\rightarrow$ image of the landscape.

It is interesting to notice that of the three groups that carried out the reading experience, readings like those of Asdrúbal and Juliana did not occur in any other group. And this was the reason why I selected this group to be the focus of this paper. The other three groups also built metonymic readings, but they were thinking on the emotional effects of vile iron dust, as pain, sadness, missing mountain, memories. And thinking of the relevance of Asdrúbal's and Juliana's readings, the group concluded that they solve the incongruities of the part that says leaving bebind in my body the landscape, vile iron dust that does not go away, because, in actual fact, the landscape remains in the body, more specifically, in the lungs, in the form of iron dust that causes the disease, which does not go away, is not curable. I also looked into the author's life in order to know if he had this disease or if he would have been talking on behalf of the Itabirian who had it. And we realized that the second possibility would have been more probable, since the author studied away from Itabira, and rarely went there, and there is no evidence that he might have had this disease.

Although Asdrúbal's and Juliana's readings have occurred only in this group, they seem to have a greater degree of relevance because they seem to better solve the incongruities than the readings of the other three groups, which were also carried out metonymically, guided by a CAUSE FOR EFFECT metonymy, but thinking of emotional effects, such as pain, sadness, memory, people missing the mountain. Would this lead to the exclusion of the reading of emotional effects? In order to answer this question, let us take a look at the next extract, and see how these emotional effects can be 
metonymically constructed, while being mediated by Asdrubal's reading and, bearing the new data in mind, I will again think of the relevance of these readings.

After the readings constructed by Asdrúbal and Fernanda, they are the ones that come to think together, co-constructing the illocutionary forces of the poem, besides another metonymic reading, in extract 4 :

\section{Extract 4}

1 Fernanda Another thing that I had thought here... I don't know if (?) someone has said this and I didn't pay attention... it is about... it is... leaving in my body its landscape, vile iron dust that does not go away... because of the iron dust inhaling, of a possible disease that may be generated in the person, s/he will remember that forever, because s/he will always, right?...in constant contact, and always having to take medication, do exams... so s/he will always remember the reason why s/he has it, and this leads to the landscape and the place.. I also thought of that...

Asdrubal And, and you spoke of the question of taking note, right?... and there is the issue of the accusation, of something really... that is... a matter of, how do we say it? It is a matter for posterity, for someone to take notes, it is not something that...

Fernanda "Beware!", right

Asdrubal Beware; it is not something to be lost. It is not that thing, it is... "what is said but is not written", do you understand? Write it down because this is an accusation...

15 Fernanda I think that there is something really serious when he says the biggest train in the world, do write it down it is criticism. It is like, look it is really serious what is happening here... they are putting a train that is the biggest in the world, do write it down, beware, do something, it is something like that. ..

On lines 3 to 8, Fernanda will broaden the inferential chain a little further constructing another metonymic reading, mediated by Asdrúbal's reading that it was the inhaling of iron dust that would cause a disease. According to Fernanda, the disease would be the CAUSE that would lead to the memory of (EFFECT) the landscape and the place (in lines 3 to 7).

Following that, Asdrúbal and Fernanda co-construct some possibilities of illocutionary forces for the poem: accusation, criticism, awareness (beware) or persuasion (to do something), indicating that this level of 
interpretation is even more undetermined (Leech 1983; Zanotto \& Moura 2002). They are mainly based on textual clues: the biggest train in the world, do write it down. Inferences of possible forces are also activated by a CAUSE FOR EFFECT metonymy. So the chain co-constructed in extract 4 is:

Inhaling the landscape (iron dust) $\rightarrow$ disease (CAUSE FOR EFFECT metonymy) $\rightarrow$ remembering (CAUSE FOR EFFECT metonymy) $\rightarrow$ criticism, accusation, awareness, persuasion (CAUSE FOR EFFECT metonymy)

If, in extract 4, we see the construction of a metonymic reading as an emotional memory effect, in extract 5, the teacher justifies the reason why she had read it as pain, in the previous reading event with the same text, with some of the same students of this group. Extract 5 is important because it brings information that allows for a new view on the discussion of relevance of metonymic inferences of emotional effects.

\section{Extract 5}

1 Teacher Now, do you know why I thought of pain, and Peter, from the other group thought of it too, because Peter participated in the other group.. well... I thought, and I think that we both thought about it for the same reason; he is not here to confirm that, but he mentioned the same thing that I did ... I related it with that other poem in which the author speaks of Itabira, he says that Itabira is only a picture on the wall, and it really burts... Do you know which one? Because, as a matter of fact, the iron exploitation did take place in Itabira. And I have the information here that it was actually on his father's farm... [......

10 Teacher So here.. we see... it says that the people born in Itabira were even angry at him when he wrote this poem Itabira is just a photograph on the wall, and it really burts, here they used the word photograph; I thought it was picture... So the people from Itabira were offended, didn't they? ... "and the renown final verse was enough to cause a wrong negative impression on the city in relation to the poet."

15 Eulália êta vida besta... [what a silly life]

Teacher Indeed what a silly life..... it really is.. so, after they mention his father's farm, and...

Unable to decipher what was said

Teacher That his father's farm ... uhn... "was reconstructed and transformed in a cultural space. The original estate had been demolished in the 70s by the Vale do Rio Doce steel company...". 


\begin{abstract}
? $\quad \mathrm{Hmmm}$.
Teacher "for the construction of a mineral dam." Or, in other words, this was inside his father's farm, can you imagine?

25 Eulália The personal effect...

Teacher Yes, because it was not just any mountain. I don't know if this pulverized mountain is the one... it probably was, right? There must have been a mountain in the farm, so the idea of pain also came... you know? Because of this, we create intertextuality. And in the group that did the first experience, there was also someone who spoke of this Itabira, it really burts. So "the poet never really hid his opinion against the degradation caused by the intense exploitation of iron ore, which altered the frame of the city, the birth place of Vale do Rio Doce steel company."...I had no idea that Vale began there. And at the time there was no concern with environmental issues, do you see? In the other discussion, you said that Drummond was a visionary. Because Drummond had a view that was 50 years ahead of his time, he was already questioning this... do you see?
\end{abstract}

In lines 1-8, the teacher justifies her reading, as well as Peter's reading of pain by means of establishing an intertextual link with another poem by Drummond, in which the author speaks of Itabira, his hometown, as just a picture on the wall, and it really hurts! She also justifies the reading because the iron exploitation was carried out in his father's farm. (See lines 7-8, 10-14 and 19-21)

The teacher bases her arguments on an article from the newspaper $O$ Estado de São Paulo (The State of São Paulo), of April 28th, 2007, whose title was Itabira quer restos mortais do poeta (Itabira wants the poet's remains), that brings information about Drummond's life and his relationship with the city that had been offended by these verses ${ }^{14}$, written by the poet about the city, but that, at the time, was requesting the remains of the poet dead in 1987. Eulália answers, in line 15 , by using a verse - Eta vida besta (what a silly life!) - from another famous poem by Drummond, meaning to criticize the situation of the city that had been offended with the poet and, now wants his remains. These verses, that are rather well known, were associated to Drummond de Andrade's position 'against the degradation caused by the

14. The poem to which the newspaper article makes reference is Confidências do Itabirano, published in Sentimento do Mundo (poems of 1935-1940), whose initial verses have already been written in footnote 7 . 
intense exploitation of iron ore, which altered the frame of the city (Itabira), the birth place of Vale do Rio Doce steel company" (Kattah, 2007) ${ }^{15}$

In lines 19 to 21 , the teacher also clarifies that the iron exploitation had taken place in the farm that belonged to the poet's father, and Eulália starts to make a comment on the personal effect that this fact must have had on the poet. In lines 26 to 30, the teacher raises the hypothesis that the "pulverized mountain" might have existed in the farm itself. However, after the reading experience, the Atlas of Itabira was checked and the information found was that the mountain was five kilometers from the farm. An article by Drummond ${ }^{16}$ was also found in the Atlas stating that: "In 1954, the Estate was no longer the property of our family and, years later, Companhia Vale do Rio Doce set up a dam in the place to wash and recover the residues of iron ore, and in doing so, it demolished, piece by piece, the entire house."

Indeed, the farm had been sold (most likely expropriated), in 1954 to Companhia Vale do Rio Doce (CVRD - which, at the time, belonged to the Federal Government). These new owners demolished the farm house in the 1970 s in order to build a dam for the ore (Kattah, 2007). This information allows the establishing of intertextual links with the information in the poem "Confidência do Itabirano", and to the information that Pico do Cauê (The name of the Pulverized Mountain) was part of the farm's landscape justifies the readings of emotional effects relating to pain, sadness, missing everything that had been lost in the poet's life. Besides, considering the three initial stanzas (that had been suppressed in the ENEM exam), the strong affective relation that Drummond had with the mountain becomes more evident:

15. Kattah, Eduardo (2007) Itabira quer restos mortais do poeta. Jornal O Estado de São Paulo, Caderno 2, p. D7, April, 28, 2007.

16. Excerpt from an article entitled "Notas sobre a Fazenda do Pontal" [Observations on Pontal Farm], published in the 27th number of the newspaper "Cometa Itabirano", of April 1982. In Martins, Marcelo Pinheiro (1960) Atlas de Itabira. Itabira: Prefeitura Municipal de Itabira [Itabira City Council] 2006: 137. 


\section{A Montanha Pulverizada}

Chego à sacada e vejo a minha serra, A serra de meu pai e meu avô, De todos os Andrades que passaram E passarão, a serra que não passa.

Era coisa dos índios e a tomamos Para enfeitar e presidir a vida Neste vale soturno onde a riqueza Maior é a sua vista a contemplá-la.

De longe nos revela o perfil grave. A cada volta de caminho aponta Uma forma de ser, em ferro, eterna, E sopra eternidade na fluência.

Esta manhã acordo e

Não a encontro.

Britada em milhões de lascas

Deslizando em correia transportadora Entupindo 150 vagões

No trem-monstro de 5 locomotivas - trem maior do mundo, tomem nota foge minha serra, vai deixando no meu corpo e na ${ }^{17}$ paisagem mísero pó de ferro, e este não passa.

Carlos Drummond de Andrade. (1979/2006) Boitempo - Esquecer para Lembrar. (Boitempo - forgetting to remember) $7^{\mathrm{a}}$ ed. Rio de Janeiro: Record, p.68.

\section{The Pulverized Mountain}

I reach the balcony to see my mountain, That of my father and my grandfather, Of all the Andrades that came before me And those to come; the mountain that does not go away.

It belonged to the Indians; we took it To adorn and preside over life In this grave valley where the greatest

Wealth is to gaze at it

From a distance it reveals its weighty profile. At each step of the way it points to An eternal form of life, in iron, And in fluency blows eternity.

It's morning, I wake up and

Can't find it

Drilled into millions of fragments

Sliding down the transportation belt Filling up 150 railway carriages

In the 5 engine monster-train

The biggest train in the world, do write it down My mountain runs away

Leaving behind in my body and in the landscape Vile iron dust, and this does not go away.

Translation by Sandra Madureira e Sueli Fidalgo.

In the first stanza, the poet speaks of the mountain by using possessive forms - which depicts the idea that the mountain is a rather cherished

17. Apart from the fact that the ENEM exam does not present the full poem, there has also been a change in the penultimate verse, which read 'leaving in my body the landscape' rather than 'leaving in my body and in the landscape' as published in the 2006 Boitempo edition and in the second edition of 1974: Menino Antigo (Ancient boy\} (Boitempo - II). Rio de Janeiro: Livraria José Olympio Editora. Even if this was the result of a mistake, the resulting incongruence was very poetic and allowed for the beautiful readings made by Asdrúbal and Eulália. To my view, the possible mistake enhanced poeticalness - and this calls for an investigation to establish if it really was a mistake or the original version written by the author. 
object. He finishes this stanza with the following utterance: the mountain that does not go away - an idea that will establish an opposition with the poem's final verse: vile iron dust that does not go away. This opposition suggests an ironic reading, since the mountain that he hoped to be eternal (as he says in the third stanza), has ironically been reduced to iron dust that does not go away - in this case, because it left the disease, the remembering, the pain, the feeling of what is missed, etc. Therefore, in these three initial stanzas, one can see the predominance of the poet's affective relation with the mountain, and the idea that the mountain will be forever - ideas that will establish opposition with the dense final stanza (composed of 10 verses while the initial three stanzas are composed of 4 verses each), which is about the destruction of Pico do Cauê that becomes the Pulverized Mountain ${ }^{18}$.

Associating the initial stanzas to the other poem (Confidência do Itabirano) through the concept of intertextuality, as well as the information about the author's life, we can conclude that the readings of emotional effects (remembering, pain, and missing something that no longer exists) are also relevant readings. And if these elements - activated for the construction of inferential chains - were considered, the chains would become networks.

Therefore, it is not possible to consider any reading irrelevant, and another important factor to be considered here is the fact that the 'vile iron dust that does not go away' - being at the end of the poem - encompasses all the possible meanings/effects of the iron exploitation: the emotional meanings/effects, as well as the physical ones, and the illocutionary forces. One can say that it becomes a symbol in which all the meanings found in the poem are concentrated.

\section{Final Reflections}

My mountain / runs away

/ Leaving behind in my body / its landscape

Vile iron dust, and this / does not go away

18. Itabirians nowadays use this expression to refer to Pico do Cauê, which was about 700 meters high. Today, the visitor sees a 500-metre deep hole in the place where once one could see the mountain. 
Therefore, these final verses allowed for the co-construction of inferential chains in two directions, in students' attempt to solve the incongruities found in these verses. First, in the physical direction, leading to the inference of disease, specifically in the lungs, and its effects; and, secondly, in the emotional direction, leading to inferences like pain, remembrance.

The physical direction led to the construction of a large inferential chain, constructed in extracts 2, 3 and 4 - that were divided for analysis purposes. This inferential chain - in terms of physical effects - allowed Fernanda to infer an emotional effect as remembrance guided by a CAUSE FOR EFFECT metonymy. This reading shows that emotional effects can be inferred from physical effects, which is coherent with human nature, since human beings are not divided in mind and body, but are both at the same time. A physical ailment provokes emotional effects, and these can lead to somatizations. Therefore, when someone freely interprets, they do not break everything into pieces in order to select one sole reading of the objectivist conception, although in traditional literacy practices (Street 1984) they are forced to do so.

Therefore, the readings, co-constructed in a network, lead us to once again question the objectivist assumption of the sole reading, since it does not respect the nature of knowledge that is organized in network. In order to accept the sole reading, we would have to deconstruct the network, fragmenting it into pieces and choosing, from these pieces, the one that would be the preferred interpretation, but reducing the possibilities of signifying. However, this illusion of objectivity breaks the human being into pieces, and hampers their reasoning - stopping them from being able to construct multiple interpretations.

The Group-Think Aloud allowed the elicitation of the co-construction process of multiple readings in inferential chains (or networks) to take place. These chains show the motivation of readings, allowing participants to reflect upon the relevance of each interpretation. It seems to me that it is possible to think about relevance whilst not seeking a sole relevant reading, rather thinking of the relevance of inferential chains.

Analysis showed that the apparent data messiness and complexity has, in fact, an organization in inferential chains that were co-constructed by participants by means of metonymic and metaphoric processes. In this paper, it was possible to show the inferential chains, but it would also be important to show how these chains could be altered in networks if the 
knowledge activated for the construction of these inferences were taken into account.

\title{
ACKNOWLEDGMents
}

I would like to thank the teachers/students who participated collaboratively in the data generation and reflectively participated in the data analyses. I would also like to thank both Sandra Madureira and Sueli Fidalgo for having so poetically translated the poem. I further want to thank Gislaine Aparecida de Vilas Boas for her effort and enthusiasm to find a great amount of information in Itabira and the Itabira Atlas.

\author{
Recebido em setembro de 2009 \\ Aprovado em abril de 2010 \\ E-mail: marasophia@terra.com.br
}

\section{REFERENCES}

Barcelona, Antonio. 2002. Clarifying and applying the notions of metaphor and metonymy within Cognitive Linguistics: An update. In: René Sirven \& Ralf Pörings (Eds.) Metaphor and Metonymy in Comparison and Contrast. Berlin, New York: Mouton de Gruyter, 207-277. . 2007. The role of metonymy in meaning construction at discourse level: A case study. In Günter Radden, Klaus-Michael Köpcke, Thomas Berg and Peter Siemund (Eds.) Aspects of Meaning Construction. Amsterdam: John Benjamins, 51-75.

.2000. Metaphor and Metonymy at the Crossroads. Berlin, New York: Mouton de Gruyter.

Cameron, Lynne. 2002. Metaphors in the learning of science: A discourse focus. British Educational Research Journal, 28/5, 673-688. 2003. Metaphor in Educational Discourse. London: Continuum. 2008. Metaphor shifting in the dynamics of talk. In: Mara S. Zanotto, Lynne Cameron and Marilda C. Cavalcanti (Eds.) Confronting Metaphor in Use: An Applied Linguistic Approach. Amsterdam: John Benjamins.

Cavalcanti, Marilda. C. 1989. Interação Leitor-Texto-Aspectos de Interpretação Pragmática [Reader-Text Interaction - Aspects of Pragmatic Interpretation] Campinas: Editora da UNICAMP. 
\& Mara S. ZanotTo. 1994. Introspection in Applied Linguistics: meta-research on verbal protocols. In L. BARbara \& M. ScotT (Eds.) Reflections on Language Learning. Clevedon: Multilingual Matters Ltd, 148-156.

Denzin, Norman K. \& Yvonna S. Lincoln (Eds.) 1998. The Landscape of Qualitative Research. London: Sage.

Ericsson, K. Anders \& Herbert A. Simon. 1984. Protocol Analysis. Cambridge, Mass: MIT Press.

GiBBs, Raymond W. 1994. The Poetics of Mind: Figurative Thought, Language and Understanding. New York: Cambridge University Press.

. 2006. Open Plenary of RaAM 6 - Researching and Applying Metaphor: Ten Years on, University of Leeds, UK.

Goossens, Louis. 1990. Metaphtonymy: The interaction of metaphor and metonymy in expressions for linguistic action. Cognitive Linguistics 1/3, 323-340. . 2002. Metaphtonymy: The interaction of metaphor and metonymy in expressions for linguistic action. In René Dirven and Ralf Pörings (Eds.) Metaphor and Metonymy in Comparison and Contrast. Berlin; New York: Mouton de Gruyter.

Grice, Paul. 1975. Logic and conversation. In P. Cole \& J. Morgan (Eds.) Syntax and Semantics (vol.3) Speech Acts. New York: Academic Press.

Hilpert, Martin. 2007. Chained metonymies in lexicon and grammar. In Günter Radden, Klaus-Michael KöPcKe, Thomas Berg and Peter Siemund (Eds.) Aspects of Meaning Construction. Amsterdam: John Benjamins, 77-98.

JACOBY, Sally \& Elinor Ochs. 1995. Co-Construction: An Introduction. Research on Language and Social Interaction, 28/3: 171-183.

Kempe, Ann. 2001. No single meaning: Empowering students to construct socially critical readings of the text. In H. FeHring \& P. Greem (Eds.) Critical literacy. Norwood / South Australia: Australian Literacy Educators' Association e Newark: International Reading Association.

Kleiman, Angela B. 2006. Processos identitários na formação profissional: $\mathrm{O}$ professor como agente de letramento. [Identity processes in professional education: The teacher as a literacy agent] In Manoel L.G. CORrÊA \& Françoise Boch (Eds.) Ensino de Lingua: Representação e Letramento. [Language Teaching: Representation and Literacy] Campinas: Mercado de Letras, 75-92.

LAKOFF, George. 1993. The contemporary theory of metaphor. In Andrew Ortony (Ed.) Metaphor and Thought (2nd and revised edition) New York: Cambridge University Press, 202-251. 
LeECH, George. 1983. Principles of pragmatics. London: Longman.

Mandel, Barrett. 1987. Literature is its audience. College Teaching, 35/3: 107-110.

Moita Lopes, Luiz Paulo. 2006. Introdução: Uma Linguística Aplicada mestiça e ideológica: Interrogando o campo como linguista aplicado. In Luiz Paulo Moita Lopes (Ed.) Por uma Linguística Aplicada Indisciplinar. São Paulo: Parábola Editorial, 13-44.

Moura, Heronides M. M. \& Mara S. ZanotTo. 2009. Investigando teorica e empiricamente a indeterminação da metáfora [Theoretically and Empirically Investigating the Indeterminacy of Metaphor]. Gragoatá, 26: 9-42.

O'Connor, Mary C. \& Sarah Michaels. 1996. Shifting participant frameworks: Orchestrating thinking practices in group discussion. In D. Hicks (Ed.) Discourse, Learning and Schooling. Cambridge: Cambridge University Press, 63-103.

PennyCoOK, Alastair. 1998. A linguística aplicada dos anos 90: Em defesa de uma abordagem crítica. [Applied Linguistics in the 90s: arguing for a critical approach] In Inês SignORINI \& Marilda C. CAVALCANTI (Eds.) Linguística Aplicada e Transdisciplinaridade. [Applied Linguistics and Transdisciplinary Work] Campinas: Mercado de Letras. 2001. Critical Applied Linguistics. London: Lawrence Erlbaum Associates.

PINKal, Manfred. 1995. Logic and Lexicon: The Semantics of the Indefinite. Netherlands: Kluwer Academic Publishers.

Poesio, Massimo. 1995. Semantic ambiguity and perceived ambiguity. In K. van Deemter \& S. Peters (eds.) Semantic Ambiguity and Underspecification. Stanford: CSLI Publications.

Radden, Günter, Klaus-Michael Köpcke, Thomas Berg \& Peter Siemund. 2007. Introduction - The construction of meaning in language. In: Günter Radden, Klaus-Michael Köpcke, Thomas Berg and Peter Siemund (Eds.) Aspects of Meaning Construction. Amsterdam: John Benjamins, 1-15.

Reddy, Michael J. 1979/1993. The conduit metaphor: A case of frame conflict in our language about language. In Andrew OrTONy (Ed.) Metaphor and Thought (2nd and revised edition). New York: Cambridge University Press, 164-201.

Rojo, Roxane H. R. 2006. Fazer uma linguística aplicada em perspectiva socio-histórica: Privação sofrida e leveza de pensamento. [The making 
of applied linguistics in a socio-historical perspective: experienced deprivation and lightness of reasoning] In: Luiz Paulo Moita Lopes (Ed.) Por uma Linguística Aplicada Indisciplinar. [In favor of indisciplinary applied linguistics] São Paulo: Parábola Editorial, 253-276.

Searle, John. 1993. Metaphor. In: Andrew Ortony (Ed.) Metaphor and Thought. $2^{\text {nd }}$ ed. Cambridge: Cambridge University Press, 83-111.

SPerber, Dan and Deirdre Wilson. 1995. Relevance - Communication E Cognition (2nd edition). Oxford: Blackwell.

Stake, Robert E. 1998. Case Studies. In Norman, K. Denzin \& Yonna, S. Lincoln, Strategies of Qualitative Inquiry. London: Sage, 86-109.

Street, Brian V. 1984. Literacy in Theory and Practice. Cambridge: Cambridge Univ. Press.

Zаnотто, Mara Sophia. 1995. Metáfora, cognição e ensino de leitura [Metaphor, cognition, and the teaching of reading]. D.E.L.T.A., 11/2: 241-254.

1997. A Leitura como evento social para um enfoque bumanístico do ensino de linguas [Reading as a social event for a bumanistic approach to language teaching]. Paper presented at XIX Congresso Mundial da FIPLV, Recife, Brazil.

. 1998. A Construção e a indeterminação do significado metafórico no evento social de leitura [The construction and indeterminacy of metaphorical meaning within the social reading event]. In Vera L.M. PaIVA. Metáforas do Cotidiano [Daily Metaphors]. Belo Horizonte: Editora da UFMG,13-38.

\& Heronides M. M. Moura. 2002. Indeterminacy and negotiation of meaning. In: Jef Verschueren, Jan-Ola Östman, Jan Blommaert \& Chris Bulcaen (Eds.) The Handbook of Pragmatics. Supplement 2000. Amsterdam, John Benjamins, 1-13.

\& Palma, Dieli V. 2008. Opening Pandora's Box: Multiple readings of a metaphor. In Mara Sophia ZanOTTO, Lynne CAMERON and Marilda Cavalcanti (Eds.) Confronting Metaphor in Use: An Applied Linguistic Approach. Amsterdam: John Benjamins.

, Lynne Cameron \& Marilda C. Cavalcanti (Eds.) 2008. Confronting Metaphor in Use: An Applied Linguistic Approach. Amsterdam: John Benjamins. 